\title{
Development of Science Learning Tools on Critical Thinking Ability and Student Learning Outcomes
}

\author{
Sri Wahyuni ${ }^{*}$, Sutarto Hadi $^{2}$, Suryajaya ${ }^{3}$
}

${ }^{1}$ Masters Program of Natural Sciences Teaching, Lambung Mangkurat University, Banjarmasin, Indonesia

${ }^{2}$ Department of Mathematics Education, Faculty of Teacher Training and Education, Lambung Mangkurat University, Indonesia

${ }^{3}$ Department of Physics, Faculty of Mathematics and Natural Science, Lambung Mangkurat University, Indonesia

DOI: $10.36348 /$ jaep.2020.v04i06.008

| Received: 30.05 .2020 | Accepted: 09.06.2020 | Published: 12.06.2020

*Corresponding author: Sri Wahyuni

\section{Abstract}

The purpose of this study is to produce a science learning tool with a valid, practical, and effective guided inquiry model. The subjects of the study were 8th grade students at SMPN 1 Martapura Timur. The development model used is the Tessmer model, which includes: 1) self-evaluation, 2) expert test, 3) individual test, 4) small group test and 5) field test. Descriptive quantitative research methods. The research subjects consisted of three individual student trial subjects, 12 small group test subjects. Subjects of the field test students were 30 students. Determination of research subjects in a purposive manner, namely students who have high, medium, and low academic ability. The results showed that the science learning tools were valid, practical and effective. Validation is shown from the results of the validation of 3 experts categorized as very valid and the test readability of teaching materials and worksheets by students who are categorized very well. Practically used because partner teachers are able to carry out learning activities. Effectively used based on the observed parameters namely 1) learning achievement test with $77 \%$ completeness, 2) students' critical thinking skills (analysis and drawing conclusions) are very good, while (interpretation, evaluation, explanation and independence) are good, 3) participant psychomotor skills very good students, 4) the behavior of students' characteristics (thorough and responsibility) on average is very good, 5) the social skills of students (working together and contributing ideas) on average are very good and the results of spiritual attitudes towards gratitude are very good categorized . The conclusion is that the learning tools developed meet the valid, practical and effective criteria.

Keywords: Learning tools development, critical thinking skills, learning outcomes.

Copyright @ 2020: This is an open-access article distributed under the terms of the Creative Commons Attribution license which permits unrestricted use, distribution, and reproduction in any medium for non-commercial use (NonCommercial, or CC-BY-NC) provided the original author and sources are credited.

\section{INTRODUCTION}

Education in Indonesia is needed to develop Science and Technology (IPTEK) which is useful for expanding knowledge while technology is a supporting factor for that knowledge. In this case the teacher has an important role as educators to direct students into the learning process so that they can obtain learning goals in accordance with what is expected. In addition to the teacher aspects of the curriculum also supports education. The curriculum used is the 2013 curriculum. Pratami [1] curriculum changes need to be applied strategies, models, techniques, approaches, and learning methods that are in accordance with the concepts being taught. This aims to make it easier for students to understand the material delivered by the teacher. In addition, students also have an important role in improving the quality of education by changing the form of student learning, for example students who were originally passive should be more active in following the learning process.

Natural Sciences is a collection of knowledge that is arranged systematically about natural phenomena. The development of science is not just a collection of facts, but the existence of scientific methods and scientific attitudes. Science education is expected to be a vehicle for students to learn about themselves and the natural environment, as well as the prospects for further development in applying it in their daily lives. Therefore, it is demanded to master science in an integrated manner. The learning process emphasizes providing direct experience to understand the natural environment around it naturally. The concepts conveyed in the science learning process are currently not widely used by students to solve problems. Most students have not been able to utilize the science knowledge they have to solve any problems that arise in real life. If this is allowed to continue, the 
critical thinking skills that we hope will be difficult to achieve. The development of students' potential can be achieved by creating an atmosphere of well-planned learning.

According to the results of a survey conducted to several teachers who teach science lessons in schools, that most teachers have not done learning that planned to lead to students' critical thinking skills. As one of the factors supporting the success of the learning process, educators need to help students to improve learning outcomes and critical thinking skills through learning models that can support students to learn actively. To improve the quality of learning, one of them is to improve learning patterns by applying learning tools that are considered effective and efficient to be applied in the classroom. According to Depdiknas [2] it is necessary to develop learning tools that are in accordance with (1) the characteristics of students, (2) the availability of teaching materials in accordance with the current curriculum, (3) guidelines for solving problems.

During the learning process, the teacher needs to create a science learning tool that can bring students to gain direct learning experience with natural surroundings to improve the learning outcomes of science, one of the learning models that can be used is the guided inquiry model. Where with this guided inquiry model students are guided to find a concept / fact, so this is also a way to practice students' critical thinking skills. The guided inquiry model is a learning model that is suitable for exploring students' critical thinking skills. Inquiry-based learning provides opportunities for students to continue to develop themselves to the fullest potential in terms of cognitive, affective, and psychomotor.

Inquiry learning strategy is a series of learning activities that emphasize the process of thinking critically and analytically to find and find answers for themselves of a problem in question. Learning material is not given directly. The role of students in this strategy is to find and find their own subject matter while the teacher acts as a facilitator and guide students to learn. The thought process itself is usually carried out through questions and answers between teachers and students [3]. Natural Sciences are widely applied in daily life making science as an important subject that must be mastered by students to face future challenges. This can be achieved if education in schools not only prioritizes mastery of concepts but is also directed at higher-order thinking abilities (HOTs). Higher-order thinking skills include critical thinking skills and creative thinking skills.

According to Dewi [4], based on his research entitled the development of integrated science learning tools with guided inquiry settings to improve students' understanding of scientific concepts and performance, obtained the validity of learning devices is in the very valid category with the validity value of student books 3.57 and teacher handbooks 3.63 , the practicality of the learning device is in the very practical category, with the value of the implementation of the learning device in the practical and very practical category, the average value of the teacher's response is 3.87 and the student's response is 3.66 , the effectiveness of the device, the average value of concept understanding 85.16 and scientific performance in the form of performance and attitude assessment is above the KKM, so it is declared $100 \%$ complete. This means, learning tools meet valid, practical and efficient criteria so that they can be implemented in a broad scope.

\section{RESEARCH METHODS}

This research is a developmental research, because it develops guided inquiry learning tools to practice critical thinking skills for junior high school students. The tool developed is the Learning Implementation Plan (RPP), teaching materials, worksheets for students (LKPD), assessment sheets (LP). Research on the development of the substance material and its characteristics, junior high school level uses the formative evaluation development model by Tessmer. The product intended in this study is an integrated science learning device with a valid, practical, and effective guided inquiry setting so as to improve student learning outcomes and critical thinking skills. The trial design is guided by the formative evaluation flow design. The subject of expert trials was determined purposively, namely 3 lecturers based on expertise in the field of science education, whereas for trials on students using a sample of 45 people. The type of data collected is in the form of validity data set by a team of experts, Questionnaire, Practicality data, and effectiveness data.

\section{RESEARCH RESULTS AND DISCUSSION Learning Tools Validity}

Validated learning tools include syllabus, lesson plans, teaching materials, LKPD and learning outcomes tests on substance material and its characteristics. The validity of the learning device is measured based on the validator's assessment.

Table-1: Learning Tools Validation Results

\begin{tabular}{|l|l|l|l|l|}
\hline No. & Tool Components & Mean & Validity Percentage (\%) & Category \\
\hline 1. & Sylabus & 3.6 & 90 & Very Valid \\
\hline 2. & Lesson Plans & 3,56 & 89,06 & Very Valid \\
\hline 3. & Worksheet & 3,7 & 92,5 & Very Valid \\
\hline 4. & Learning Material & 3,75 & 93,7 & Very Valid \\
\hline 5. & Product Cognitive Assessment Sheet & 3,5 & 87,5 & Very Valid \\
\hline 6. & Process Assessment Sheet & 3,75 & 93,7 & Very Valid \\
\hline
\end{tabular}


The learning tool developed in this study is a learning tool on the subject matter and its characteristics using the guided inquiry model to train students' critical thinking skills. In general, after going through the revision phase of learning tools that have been developed include syllabus, lesson plans, teaching materials, LKPD, cognitive LP products, cognitive LP processes, and psychomotor LP learners. The overall validation results stated that categorized as very valid according to Akbar [5].

This is in accordance with Akker [6] that validation is one of the criteria that determines the quality of a product. The assessment instrument must be valid to reduce errors in the measurement process. Based on the results of the validator's assessment of the syllabus showed that of the 10 components assessed there were 6 components that were declared highly valid and 4 components that were declared valid, with minor revisions in the form of suggestions from the validator. The syllabus developed by researchers follows the steps of the guided inquiry model by taking into account the Competency Standards and Basic Competencies of the Substances and their Characteristics. In addition, the assessment instruments carried out vary so that they can measure the cognitive, skills, and attitudes of students.

This is in line with Martin [7] that inquiry learning emphasizes the development of cognitive, affective, and psychomotor aspects in a balanced way, so that learning is more meaningful. Students have the ability to observe, interpret, predict, analyze, assess, and communicate various problems encountered.

Based on the results of the validator's assessment of the RPP shows that of the 16 components assessed there were 13 components that were declared very valid and 3 components were declared valid (can be used with minor revisions) in the form of suggestions from the validators. But overall this RPP is included in the very valid category which means that the components of the preparation of the RPP have been fulfilled correctly.

Learning activities in the lesson plan have been attempted to provide learning experiences that involve mental and physical processes, namely through learning with guided inquiry models. The results of development tests in the field show that the CSPs are appropriate after repairs. This is in line with Mulyasa [8] that the results of the development test also provide improvement so that the RPP can fulfill the planning and implementation functions. The planning function is the RPP function as a motivator so that the teacher is better prepared to carry out learning activities with careful planning, while the implementation function is the RPP function to streamline the learning process in accordance with what has been planned.

Based on the results of the validator's assessment of LKPD showed that of the 10 components assessed there were 7 components that were declared highly valid and 3 other components that were declared valid but overall included in the very valid category.

Based on the results of the validator's assessment of teaching materials showed that of the 16 components assessed there were 12 components that were declared very valid and 4 other components that were declared valid but overall included in the valid category. But the overall score in the category is very valid. This is in line with Amri and Ahmadi [9] that teaching materials are prepared with the aim of providing material that is in line with curriculum requirements by considering the needs of students, helping in obtaining alternative materials that are sometimes difficult to understand in textbooks, and making it easier for teachers to carry out learning. Jaya et al., [10] also stated that the learning tools that have been developed are suitable to be used if they meet the minimum valid categories as specified.

\section{Practicality of Learning Devices}

Three small group trials were conducted. In the implementation at this stage learning is carried out by partner teachers so there is no bias. Small group trials using learning tools in class are data taken from the assessment of 2 observers on the implementation of lesson plans developed by researchers. A summary of the assessment of the feasibility of learning using a science learning tool with a guided inquiry model of the Substance and Its Characteristics in grade 8 is presented in Table-2.

Table-2: Results of the Implementation of RPP in Small Group Tests

\begin{tabular}{|l|l|l|l|l|l|l|}
\hline & Activity Phase & \multicolumn{3}{|l|}{ Meeting } & Score & Category \\
\cline { 2 - 7 } & & $\mathbf{1}$ & $\mathbf{2}$ & $\mathbf{3}$ & & \\
\hline Opening Phase & 3.5 & 4 & 4 & 3.8 & Very good \\
\hline Main Phase & 3.6 & 3.6 & 3.8 & 3.6 & Very good \\
\hline Closing Phase & 3.5 & 4 & 4 & 3.8 & Very good \\
\hline Note: $3<\mathrm{X} \leq 4=$ Very Good $1<\mathrm{X} \leq 2=$ Good Enough \\
& $2<\mathrm{X} \leq 3=$ Good $\mathrm{X} \leq 1=$ Not Good
\end{tabular}

Table-2 explains that the categorized preliminary activities are very good as well as the core and closing activities. The achievement of the implementation of the lesson plan is due to the partner teacher being able to carry out the implementation of the lesson plan. Then the actual practicality test of the learning device is carried out. 
The practicality of the developed learning device refers to the implementation of the learning process in class in accordance with the research design developed in the learning device. Learning activities show that the activities of teachers and students tend to increase at each meeting. The ability of students to do practical activities is increasing and teachers are increasingly accustomed to acting as facilitators for students. Nevertheless, there are some obstacles that are still visible, including some students still having difficulty in understanding and doing activities, as well as making practicum reports due to the lack of serious students to read and examine the activities presented.

There are some students who seem passive in group discussions. Handling this obstacle at the next meeting will be carried out by giving guidance to the group of students, and giving direction for the group to read work procedures before carrying out practical activities. In general, the implementation of the third meeting had a positive impact. This is indicated by an increase in the average score of the learning device implementation from the second meeting to the third meeting. This is in line with the results of Khan's research [11] in his research explaining that inquiry learning requires teachers to invite their students to be actively involved in learning through real life situations, integrate their own knowledge to solve problems so that students become active and do not feel bored quickly in learning. A good learning tool must be practical, easy to implement and efficient in terms of cost and energy. In this research, the term practicality can be used by looking at what is developed and can be applied in reality in accordance with the objectives to be achieved.

\section{Effectiveness of Learning Tools}

The effectiveness of learning devices based on cognitive learning outcomes and critical thinking skills.

\section{Student Learning Outcomes (Cognitive)}

Student learning outcomes in the field test can be seen in Table-3.

Table-3: Student learning outcomes in Field Test Before and After using Learning Tools

\begin{tabular}{|l|l|l|l|l|l|}
\hline No & Component & Pre-test & Post-test & Gain & N-Gain \\
\hline \multirow{2}{*}{} & The complete amount & 11 & 23 & & \\
\cline { 2 - 6 } & Average & 55,93 & 74,93 & 19 & 0,41 \\
\cline { 2 - 6 } & Percentage of mastery & $37 \%$ & $77 \%$ & & \\
\hline
\end{tabular}

Based on the average cognitive score before and after learning an increase of gain score is 19 points. When viewed from the normalized gain (n-gain) an increase of 0.41 points or in the medium category. Based on Table 3 in the field test before being treated the number of students who completed as many as 11 people with a percentage of $37 \%$ and after being treated with a guided inquiry learning model the number of participants who completed became increased by 23 students with a percentage of $77 \%$. Based on this it can be concluded that the learning device is said to be effective.

At the pretest in the small group test there were 4 participants who completed the Ddik, while in the field test there were 11 students who completed the learning outcomes. This happens because students have not participated in learning on the subject matter and its previous characteristics, so the answers of students at the time of the pretest are only based on the students' initial knowledge. While the posttest results have increased although not $100 \%$ complete.

The results were obtained because students had followed the learning of the Substance and its Characteristics. In addition, mastery learning is related to the activeness of students in learning substances and their characteristics so that they are easy to remember and understand. This is in accordance with the theory of constructivism where knowledge is formed not only from mere objects but also depends on the individual itself as the subject that captures every object that is observed. Therefore, knowledge is not stative but dynamic depending on the individual who sees and constructs it [3]. This is in line with Abdi's research [12] stating students who are taught with inquiry-based learning have higher learning outcomes than students who are taught through traditional methods. Vlassi and Karaliota [13] also stated that through comparative study of learning using inquiry and traditional models of the topic of Substance Structure shows the results of research using inquiry models are superior to traditional methods. In line with Simsek and Pinar [14] research, inquiry-based learning can improve students 'conceptual understanding and develop students' science process skills.

\section{Critical Thinking Skills}

The assessment of critical thinking skills in the field test was obtained from LKPD activities in the learning process in class as a group divided into 6 groups consisting of 5 students each. The assessment of critical thinking skills aims to determine the effectiveness of the learning tools developed. Observations were made based on indicators of critical thinking skills including interpretation, analysis, evaluation, conclusions, explanations and independence. The results of students' critical thinking skills can be seen in Table-4. 
Table-4: Average Assessment of Students' Critical Thinking Skills

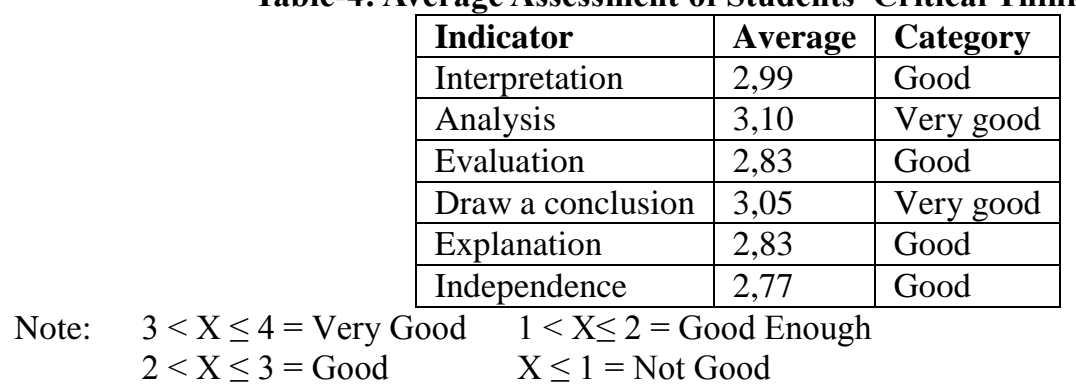

Critical thinking skills are part of higher order thinking skills. Critical thinking skills emphasize the process of forming skills in gaining knowledge and communicating their acquisition. Research conducted during the three meetings was an aspect of critical thinking skills observed in each meeting in accordance with the learning activities undertaken. Based on Table, shows the ability of independence to make corrections has the lowest average, but still in the good category.

Critical thinking skills are needed and should be owned by students [15], inquiry-based learning has a significant positive impact on students' critical thinking skills according to Duran [16], in his research, Lohner et al., [17] also found the fact that inquiry learning is effective in requiring students to build and evaluate their own hypotheses, and obtain their own conclusions. This is in line with Muchtar and Harizzal [18] and Fahmi and Irhasyuarna [19] also find the fact that weak knowledge of concepts will continue to the difficulties of students in solving complex problems and arrive at mistakes in taking or assessing conclusions. For this reason learning using the guided inquiry model becomes one of the strategies carried out by the teacher so that learning activities are more enjoyable so as to form a learning process such as positive attitudes and perceptions about learning, acquire and integrate knowledge, expand and improve knowledge, use knowledge meaningfully, and get used to thinking critical.

\section{CONCLUSION} concluded that:

Based on the results of the study it can be

1. The science learning tool uses the guided inquiry model of the subject matter and its characteristics are classified as very valid including syllabus, lesson plans, LKPD, teaching materials, LP Products, and LP critical thinking obtained from three experts.

2. Practicality of development learning tools using guided inquiry models of substances and their characteristics classified as practical obtained from the implementation of lesson plans (preliminary activities, core activities, and closing) categorized Very well. This is supported by the practicality of expectations and actual practicality. Achievement of the implementation of this lesson plan is due to the availability of good learning tools and partner teachers are able to carry out the implementation of the lesson plan. In addition, students can use teaching materials and LKPD made by researchers.

3. The effectiveness of the science learning tool the results of the development using the guided inquiry model of the substance and its characteristics can be seen from:

4. Learning outcomes of students who have completed as many as 23 people with a percentage of completeness of $77 \%$ and have reached the KKM set by the school that is equal to 70 .

5. Critical thinking skills of students include analysis, drawing conclusions, categorized very well while interpreting, evaluating explanations and independence, categorized well.

\section{REFERENCES}

1. Pratami, T. D. (2015). Implementasi Model Pembelajaran ARIAS pada Pembelajaran IPA dalam Kurikulum 2013. Prosiding Seminar Nasional Pendidikan Sains Tahun 2015 "Pembelajaran dan Penilaian Sains Sesuai Tuntutan Kurikulum 2013. Surabaya, 24 Januari 2015.

2. Depdiknas. (2008). Panduan Pengembangan Bahan Ajar. Jakarta: Direktorat Pembinaan SMA, Dirjen Mandikdasmen, Depdiknas.

3. Sanjaya, W. (2011). Perencanaan Pengajaran Berdasarkan Pendekatan Sains. PT Bumi Aksara: Jakarta.

4. Kumala, D. (2013). Pengembangan perangkat pembelajaran IPA terpadu dengan setting inkuiri terbimbing untuk meningkatkan pemahaman konsep dan kinerja ilmiah siswa. e-Journal Program Pascasarjana Universitas Pendidikan Ganesha. Program Studi Pendidikan IPA, Program Pascasarjana: UniversitasPendidikanGaneshaSingaraja, 3(5), 111.

5. Akbar, S. A. (2013). Instrumen Perangkat Pembelajaran. Bandung: Remaja Rosdakarya.

6. Akker, J. V. D., Gravemeijer, K., Mckenney, S., \& dan Nieveen, N. (2006). Educational Design 
Research. Educational design research seminar organized by the Netherlands Organization for Scientific Research; Program Council for Educational Research (NWO/PROO): Netherlands.

7. Martin, D. J. (2005). Prosess - Oriented Inquiry A Contructivist Approach to Early Chilhood Science Education : Teaching Teachers to Do Science. Journal of Elementary Science Education.

8. Mulyasa, E. (2008). Implementasi kurikulum tingkat satuan pendidikan: kemandirian guru dan kepala sekolah. Bumi Aksara.

9. Amri, S., \& dan Ahmadi, I. K. (2010). Proses Pembelajaran Kreatif dan Inovatif dalam Kelas. Jakarta: Prestasi Pustakarya.

10. JAYA, I. M., Sadia, I. W., \& Arnyana, I. B. P. (2014). Pengembangan perangkat pembelajaran biologi bermuatan pendidikan karakter dengan setting guided inquiry untuk meningkatkan karakter dan hasil belajar siswa SMP. Jurnal Pendidikan dan Pembelajaran IPA Indonesia, 4(1).

11. Khan, M. S., Hussain, S., Ali, R., Majoka, M. I., \& dan Ramza, M. (2011). Effect of inquiry method on achievement of student in chemistry of secondary level. International Jurnal of Academic Research, 3(1): 955-959.

12. Abdi, A. (2014). The Effect Inquiry-Based Learning Method on Student Academic Achievement in Science Course. Universitas Journal of Education Research, 2(1):37-41.
13. Vlassi, M., \& Karaliota, A. (2013). The comparison between guided inquiry and traditional teaching method. A case study for the teaching of the structure of matter to 8th grade Greek students. Procedia-Social and Behavioral Sciences, 93, 494-497.

14. Şimşek, P., \& Kabapınar, F. (2010). The effects of inquiry-based learning on elementary students' conceptual understanding of matter, scientific process skills and science attitudes. ProcediaSocial and Behavioral Sciences, 2(2), 1190-1194.

15. Beaumont, J. (2010). A Sequence of Critical Thinking Tasks. TESOL Journal, 1(4):1-22.

16. Duran, M., \& Dökme, İ. (2016). The effect of the inquiry-based learning approach on student's critical-thinking skills. Eurasia Journal of Mathematics, Science \& Technology Education, 12(12), 2887-2908.

17. Löhner, S., van Joolingen, W. R., Savelsbergh, E. R., \& van Hout-Wolters, B. (2005). Students' reasoning during modeling in an inquiry learning environment. Computers in Human Behavior, 21(3), 441-461.

18. Muchtar, Z. (2012). Analyzing of students'misconceptions on acid-base chemistry at senior high schools in medan. Journal of Education and Practice, 3(15), 65-74.

19. Fahmi, F., \& Irhasyuarna, Y. (2017). The Misconceptions of Senior High School Students in Banjarmasin on Chemical Bonding. Journal of Education and Practice, 8(17), 32-39. 